\title{
Meningkatkan Aktivitas Belajar Siswa Dalam IPA Terpadu Menggunakan Penilaian Portofolio Melalui Lesson Study di SMP Sekolah Alam dan Sains Aljannah Jakarta
}

\author{
Nurbaity, Sondang, dan Wahyu Rochadi Utami \\ Jurusan Kimia FMIPA Universitas Negeri Jakarta, e-mail:nurbaity47@gmail.com
}

\begin{abstract}
Abstrak: Penelitian ini bertujuan untuk meningkatkan aktivitas belajar siswa kelas VIII SMP Sekolah Alam dan Sains Aljannah pada pembelajaran kimia menggunakan penilaian portofolio melalui implementasi lesson study. Metode yang digunakan dalam penelitian adalah deskriptif kualitatif. Penilaian portofolio dilakukan dalam empat kali proses pembelajaran pada materi pokok Zat aditif makanan, dan zat aditif dan Psikotropika, dengan aktivitas siswa yang beragam dan bentuk portofolio juga bervariasi. Hasil penelitian menunjukkan bahwa ada peningkatan aktivitas belajar siswa dalam pembelajaran kimia dalam IPA terpadu dengan menggunakan portofolio melalui implementasi lesson study.
\end{abstract}

Kata Kunci: lesson study, aktivitas belajar siswa, dan portofolio

\begin{abstract}
This research aimed is to enhance students' study activities of VIII grade at SMP Sekolah Alam and Sains Aljannah on Chemistry Lesson under integrated Sains. The Chemistry Lesson is performed using portofolio assessment through Lesson Study implementation. The research methode is qualitative description. The portofolio assessment is done four times of lesson process on food preservative, addictive and psychotropic topic. The portofolio assessment consists of various students' study activities and portofolio forms. The result indicates that there is increase of students' study activities on Chemistry Lesson under integrated science using portofolio assessment through Lesson Study implementation.
\end{abstract}

Key words: lesson study, students study activities, and portofolio

\section{Pendahuluan}

Dengan dicanangkannya wajib belajar 9 tahun oleh Pemerintah, maka semua anak Indonesia harus bersekolah. Pernyataan tersebut menyiratkan bahwa sekolah masa kini adalah milik semua anak tidak terkecuali untuk anak-anak yang perlu penanganan khusus dalam proses pembelajaran di sekolah. Potensi belajar setiap anak harus dapat diwujudkan. Berdasarkan fakta, semua anak yang diharapkan bersekolah memiliki latar belakang yang berbeda-beda, seperti kecerdasan, talenta, minat dan kebutuhan yang beragam. Dalam upaya mengatasi hal ini, muncul sekolah-sekolah alternatif yang memiliki sistem yang berbeda dari sekolah-sekolah umum yang sudah ada guna mencari bentuk dan sistem yang ideal dalam mengembangkan potensi siswa secara maksimal. Salah satu sekolah alternatif yaitu sekolah alam yang menggunakan pendekatan berbasis alam dalam pembelajarannya. Sistem pembelajaran ini lebih menekankan siswa berpikir kritis terhadap semua hal yang ditemui dan dipelajari serta mengaitkannya dengan alam sekitar, sehingga menjadi manusia yang senantiasa bijak terhadap alam, tempat di mana mereka berada. Sekolah alam mulai berdiri di Indonesia sejak tahun 1996. Pada awalnya sekolah alam ditujukan bagi siswa yang berkebutuhan khusus (tunagrahita) dengan tujuan agar siswa tersebut dapat mandiri dan mempertahankan diri di dunia nyata yang memiliki kondisi heterogen. Dalam perkembangannya, saat ini sekolah alam bukan hanya ditujukan bagi siswa yang berkebutuhan khusus tetapi juga siswa yang normal. Sekolah alam menerapkan sistem yang berbeda dengan sekolah reguler pada umumnya. Sekolah alam menerapkan sistem sekolah inklusi yaitu penggabungan antara siswa normal dengan siswa yang berkebutuhan khusus dalam satu kelas. Staub dan Peck (1995) mengemukakan bahwa pendidikan inklusi adalah penempatan anak berkelainan tingkat ringan, sedang, dan berat secara penuh di kelas reguler (dalam Diknas, 2004: 9). Hal ini menunjukkan bahwa kelas reguler 
merupakan tempat belajar yang relevan bagi anak berkelainan, apapun jenis kelainannya dan bagaimanapun gradasinya.

Sekolah Alam dan Sains Aljannah Jakarta merupakan salah satu sekolah alam yang menerapkan sistem sekolah inklusi, yaitu menggabungkan dalam satu kelas antara siswa berkebutuhan khusus seperti autis, hiperaktif, down sindrom, dan slow learner dengan siswa normal. Banyak hal yang perlu diperhatikan dalam pembelajaran yang disebabkan oleh karena perbedaan yang ada pada diri siswa berkaitan dengan kecerdasan akademik, mental, dan bahkan kondisi lingkungan rumah, sehingga membuat aktivitas di kelas sangat beragam. Oleh karena itu, guru harus kreatif dan inovatif dalam membelajarkan siswa agar bermakna. Guru sebagai pengajar dan pendidik dihadapkan pada tantangan dalam menghadapi keanekaragaman kemampuan siswa dan latar belakang siswa. Guru harus mengamati setiap siswa di dalam kelas agar memahami keadaan emosi para siswa, gaya belajarnya, kemampuan berbahasa, konteks budaya dan latar belakangnya. Sistem pendidikan harus memungkinkan pergaulan dan interaksi antarsiswa yang beragam sehingga mendorong sikap silih asah, silih asih, dan silih asuh dengan semangat toleransi seperti halnya yang dijumpai atau dicita-citakan dalam kehidupan sehari-hari. Dalam teknis pelaksanaan pembelajaran di kelas yang beragam seperti yang dilakukan di Sekolah Alam dan Sains Aljannah, mengalami kesulitan dalam pengelolaan kelas dan mengevaluasi proses dan hasil belajar.

Lesson study dapat menjawab tantangan heterogenitas siswa dalam belajar, pembelajaran dalam Lesson study berpusat pada siswa, berbasis hands-on dan mind-on activity, daily life, dan local materials. Pembelajaran melalui lesson study dapat menciptakan situasi kelas yang kondusif dan memperoleh informasi langsung tentang aktivitas belajar siswa.

Pada pelaksanan lesson study di sekolah inklusi, sebelum membuat perencanaan pembelajaran, didahului dengan observasi untuk mengenal dan mengetahui kondisi awal siswa, sehingga dapat diketahui kecenderungan gaya belajar, modalitas belajar (visual, auditori, kinestetik) siswa. Dari hasil observasi tersebut guru dapat merancang pengalaman belajar yang berorientasi pada aktivitas siswa di kelas sesuai dengan gaya belajar mereka. Guru dapat mengetahui perubahan perkembangan aktivitas siswa melalui instrumen pembelajaran yang telah disiapkan menggunakan portofolio.

Penilaian portofolio sebagai alat penilaian perkembangan dan aktivitas siswa dalam pembelajaran merupakan penilaian berbasis kelas yang berorientasi pada penilaian proses dan produk berupa penilaian terhadap hasil karya siswa dalam bentuk tulisan, lisan, foto, gambar, dan rekaman. Penilaian portofolio berbasis kelas merupakan teknik penilaian yang bersifat open ended, koleksi data yang menggambarkan kinerja dan prestasi siswa yang disusun secara sistimatis (Robert Tierney, et al. 1991: 41), Penilaian portofolio siswa dalam pembelajaran kimia pada IPA terpadu melalui lesson study di Sekolah Alam dan Sains Aljannah diharapkan dapat meningkatkan aktivitas belajar siswa.

Rumusan masalah dalam penelitian sebagai berikut apakah implementasi lesson study dalam pembelajaran IPA Terpadu, menggunakan penilaian portofolio dapat meningkatkan aktivitas siswa? Penelitian ini bertujuan untuk mengetahui peningkatan aktifitas belajar siswa kelas VIII SMP Sekolah Alam Aljannah Jakarta, dalam pembelajaran IPA Terpadu menggunakan penilaian portofolio dengan melalui lesson study.

\section{Kajian Literatur Lesson Study}

Lesson study adalah suatu model pembinaan profesi pendidik melalui pengkajian pembelajaran secara kolaboratif dan berkelanjutan berlandaskan prinsip-prinsip kolegalitas dan mutual learning untuk membangun komunitas belajar. Secara harfiah, lesson study dapat diterjemahkan menjadi "belajar dari pembelajaran". Pengetahuan materi ajar maupun keterampilan guru untuk membelajarkan siswa, dibangun dalam komunitas belajar melalui sharing pendapat diantara anggota komunitas dengan lebih menekankan pada prinsip-prinsip kolegalitas dan mutual learning. Guru sebagai nara sumber memang perlu mengkoreksi kesalahan konsep-konsep melalui sharing pendapat yang didukung fakta dengan 
santun dan bijak, sehingga semua anggota komunitas belajar merasa nyaman.

Implementasi lesson study dalam proses pembelajaran mengizinkan observer berasal dari guru mata pelajaran yang sama atau berbeda, kepala sekolah, para pemangku kepentingan (stakeholders), komite sekolah, dan lain-lain, melakukan observasi terfokus kepada aktivitas siswa.

Dalam praktiknya, kegiatan lesson study dilaksanakan melalui tiga tahap, yaitu Plan (merencanakan), Do (melaksanakan dan mengobservasi), dan See (merefleksi) yang berkelanjutan. Skema lesson study dapat dilhat pada gambar berikut.

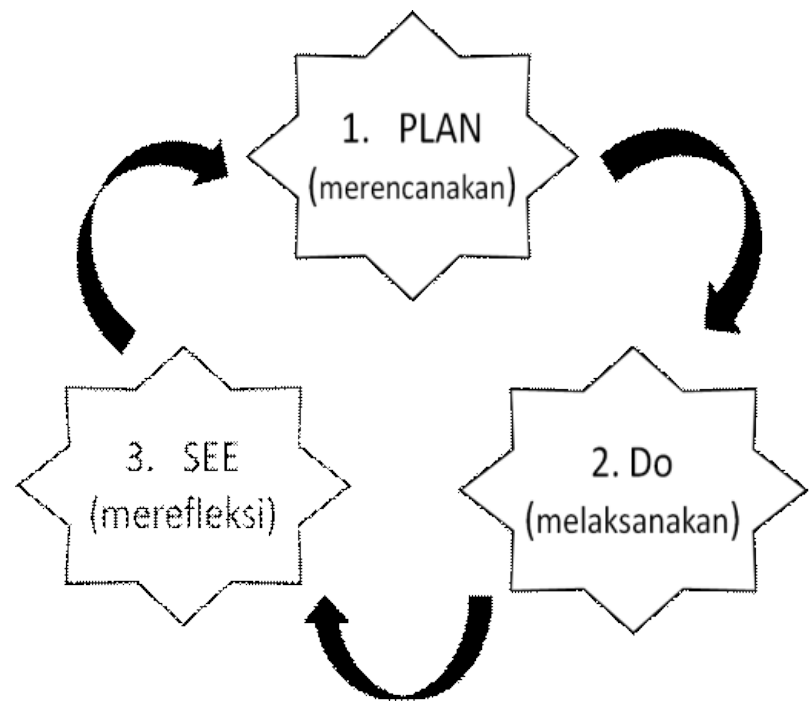

Gambar 1. Skema Kegiatan Lesson Study Sumber: Sumar Hendayana dkk, 2007. Hal.10

Tahap plan, yaitu merencanakan proses pembelajaran (RPP) dapat dimulai dengan diskusi tentang permasalahan yang ditemukan dalam pembelajaran di kelas. Permasalahan bisa saja berhubungan dengan materi ajar, strategi pembelajaran, evaluasi bahkan penyusunan instrumen pembelajaran seperti LKS dan praktikum. Permasalahan pada pedagogi, misalnya tentang metode pembelajaran yang sesuai/tepat, agar pembelajaran lebih efektif dan efisien. Selanjutnya, pada permasalahan fasilitas, bagaimana mengatasi kekurangan fasilitas pembelajaran. Untuk mengatasi masalah pembelajaran, guru secara kolaboratif mengembangkan model pembelajaran. Karateristik model pembelajaran dalam lesson study berpusat pada siswa, berbasis hands-on dan mind-on activity, daily life, dan local materials. Pada dasarnya model pembelajaran yang disusun merupakan karya kolaborasi guruguru dengan fasilitator dan nara sumber. Sebelum diimplementasikan model pembelajaran diuji coba dan dikaji ulang bersama.

Pada tahapan melaksanakan pembelajaran (do), guru model melaksanakan pembelajaran untuk menerapkan rancangan pembelajaran yang telah disusun dalam RPP dalam kelas. Langkah ini bertujuan untuk mengujicoba efektivitas model pembelajaran yang sudah dirancang. Anggota kelompok lainnya mengobservasi jalannya pembelajaran, dengan fokus observasi aktivitas siswa (bukan aktivitas guru). Selain guru anggota kelompok, guru lain (dari bidang studi berbeda), pengawas, kepala sekolah, komite sekolah, dan yang lainnya, dapat bertindak sebagai observer. Perlu diperhatikan bahwa observer tidak boleh mengganggu atau menginterupsi proses pembelajaran, sebaiknya observer berdiri disisi kiri dan kanan atau di belakang ruang kelas agar aktivitas siswa teramati dengan baik. Fokus observasi ditujukan pada interaksi siswa-siswa, siswa-guru, guru-siswa, siswa-bahan ajar, siswa-lingkungan, dan mengamati bagaimana siswa belajar. Observer mencatat dengan cermat bagaimana aktivitas siswa pada tahap awal, tahap inti, dan tahap akhir pembelajaran.

Tahap refleksi (see), Guru dan observer lainnya melakukan sharing lesson learn tentang aktivitas siswa dalam pembelajaran. Dalam kegiatan ini, guru dan observer dapat saling belajar dari pembelajaran. Guru dan kelompoknya mendapatkan umpan balik untuk memperbaiki model pembelajaran yang telah dirancang dan diimplementasikan. Berdasarkan masalah dari diskusi ini dirancang kembali pembelajaran berikutnya. Pada prinsipnya semua unsur dapat yang terlibat dalam kegiatan lesson study harus memperoleh lesson learn. Dengan demikian, kita membangun komunitas belajar melalui lesson study.

Implementasi hasil revisi model dapat dilakukan kembali oleh guru itu sendiri di kelas lain, (kalau ada kelas paralel), maupun oleh guru lain di sekolah yang sama atau sekolah yang berbeda. 


\section{Aktivitas Belajar Siswa}

Aktivitas belajar siswa sangat tergantung pada rancangan pengalaman belajar yang dibuat guru. Belajar menghasilkan perubahan perilaku anak didik yang relatif permanen, berarti guru berperan sebagai pelaku perubahan atau agent of change (Elaine B. Johnson, 2007: 18). Situasi atau kondisi akan menentukan aktivitas yang dilakukan dalam proses pembelajaran. Kegiatan siswa dalam pembelajaran melibatkan kelima alat indranya, ada yang melibatkan hanya mata, telinga dan mulut saja, namun ada juga yang melibatkan kesemua alat indranya. Dierich (dalam Hamalik, 2008) mengelompokkan kegiatan belajar ke dalam delapan kelompok yaitu: 1) Kegiatankegiatan visual: membaca, melihat gambar, mengamati eksperimen, demonstrasi, pameran, serta mengamati orang lain bermain atau bekerja; 2) Kegiatan-kegiatan lisan atau oral: mengemukakan suatu fakta atau prinsip, menghubungkan kejadian, mengajukan pertanyaan, mengemukakan pendapat, memberi saran, diskusi, wawancara, dan interupsi; 3) Kegiatan-kegiatan mendengarkan: mendengarkan presentasi, percakapan, radio, dll; 4) Kegiatan-kegiatan menulis: menulis laporan, memeriksa karangan, menulis cerita, membuat rangkuman, mengisi angket; 5) Kegiatan-kegiatan menggambar: menggambar, membuat chart, membuat grafik, diagram, peta dan pola; 6) Kegiatan-kegiatan matrik: membuat model, melaksanakan pameran, melakukan percobaan, seleksi alat-alat, menari, melakukan permainan dan berkebun; 7) Kegiatankegiatan mental: merenung, mengingat, menganalisis faktor-faktor, melihat hubunganhubungan atau korelasi, memecahkan masalah serta membuat putusan; dan 8) Kegiatan emosional: tenang, berani, berminat, dapat membedakan, dll.

Dari pengelompokan di atas dapat dikatakan bahwa aktivitas belajar siswa merupakan seluruh kegiatan belajar siswa yang ditampilkan pada proses pembelajaran baik diminta ataupun dengan inisiatif sendiri dan membantunya melakukan perubahan. Dalam pembelajaran sekolah yang berbasis alam, kegiatan diperhatikan pada aktivitas siswa. Dalam proses pembelajaran perlu juga memperhatikan gaya belajar siswa yang berkaitan dengan cara siswa bereaksi terhadap rangsangan yang diterimanya dalam pembelajaran. Menurut Ronald dan Serbrenia Sims dalam bukunya The Importance of learning styles, mengatakan bahwa secara umum hingga seseorang dewasa, setiap mereka telah mengembangkan metode dan gaya belajar mereka sendiri dan setiap guru juga telah mengembangkan gaya mengajar sendiri. Untuk mendapatkan pengalaman belajar atau mengajar yang terbaik, gaya pembelajar dan pengajar haruslah sesuai dan nyambung (dalam Yulia Jasmin, 2007: 94-95).

Para peneliti menemukan adanya berbagai gaya belajar pada siswa yang dapat digolongkan menurut kategori tertentu. Mereka berkesimpulan bahwa: a) Tiap murid belajar menurut cara sendiri yang disebut gaya belajar; b) Gaya belajar dapat ditemukan dengan melakukan serangkaian tes menggunakan instrumen yang tepa; dan c) Kesesuaian gaya mengajar dengan gaya belajar mempertinggi efektifitas belajar (Nasution, 2008).

Selanjutnya, De Porter dan Hernacki (2005) mengemukakan hal yang sama, mengatakan bahwa kunci untuk mengembangkan diri dalam setiap sesi hidupnya adalah dengan mengenal gaya belajar. Gaya belajar merupakan kombinasi dari bagaimana seseorang menyerap, mengatur dan mengolah informasi. Cara termudah menyerap informasi disebut modalitas, sedangkan cara mengatur dan mengolah informasi adalah dominasi otak. Pada awal pengalaman belajar adalah mengenali modalitas, yaitu: visual, auditorial dan kinestetik. Kecenderungan terhadap satu modalitas membentuk gaya belajar. Ciri-ciri gaya belajar siswa dapat dilihat pada Tabel 1. Berdasarkan ciri gaya belajar dapat dikatakan bahwa aktivitas belajar siswa akan meningkat apabila gaya belajar siswa sama dengan gaya mengajar guru atau aktivitas siswa di kelas sangat dipengaruhi oleh gaya belajar siswa, maka penilaian aktivitas belajar siswa harus disesuaikan dengan tipe gaya belajarnya.

\section{Penilaian Portofolio}

Penilaian portofolio merupakan satu alternatif untuk meningkatkan kemampuan peserta didik (student achievement) melalui evaluasi umpan balik dan penilaian sendiri (Sumarna $S$ dan $M$. Hatta, 2004: 71). Secara umum, penilaian porto- 
Nurbaity, Sondang, dan Wahyu Rochadi Utami, Meningkatkan Aktivitas Belajar Siswa Dalam IPA Terpadu Menggunakan Penilaian Portofolio .....

Tabel 1. Ciri-ciri Gaya Belajar Siswa

\begin{tabular}{|c|c|c|}
\hline Gaya Belajar Visual & Gaya Belajar Auditori & Gaya Belajar Kinestetik \\
\hline Rapi dan teratur & $\begin{array}{l}\text { Berbicara kepada diri sendiri saat } \\
\text { bekerja }\end{array}$ & Berbicara dengan perlahan \\
\hline Berbicara dengan cepat & Mudah terganggu oleh keributan & Menanggapi perhatian fisik \\
\hline $\begin{array}{l}\text { Perencana dan pengatur jangka } \\
\text { panjang yang baik }\end{array}$ & $\begin{array}{l}\text { Menggerakan bibir dan mengucap- } \\
\text { kan tulisan di buku ketika membaca }\end{array}$ & $\begin{array}{l}\text { Menyentuh orang untuk menda- } \\
\text { pat perhatian mereka }\end{array}$ \\
\hline Teliti terhadap detail & $\begin{array}{l}\text { Senang membaca keras dan } \\
\text { mendengarkan }\end{array}$ & $\begin{array}{l}\text { Berdiri dekat ketika berbicara } \\
\text { dengan orang }\end{array}$ \\
\hline $\begin{array}{l}\text { Mementingkan penampilan, baik } \\
\text { dalam pakaian maupun presentasi }\end{array}$ & $\begin{array}{l}\text { Dapat mengulangi kembali dan } \\
\text { menirukan nada, birama, dan } \\
\text { warna suara }\end{array}$ & $\begin{array}{l}\text { Selalu berorientasi pada fisik } \\
\text { dan banyak bergerak }\end{array}$ \\
\hline $\begin{array}{l}\text { Pengeja yang baik dan dapat me- } \\
\text { milih kata-kata yang sebenarnya } \\
\text { dalam pikiran mereka }\end{array}$ & $\begin{array}{l}\text { Merasa kesulitan menulis, tetapi } \\
\text { hebat dalam bercerita }\end{array}$ & $\begin{array}{l}\text { Mempunyai perkembangan awal } \\
\text { otot-otot yang besar }\end{array}$ \\
\hline $\begin{array}{l}\text { Mengingat apa yang dilihat, dari- } \\
\text { pada apa yang didengar }\end{array}$ & $\begin{array}{l}\text { Berbicara dalam irama yang } \\
\text { terpola }\end{array}$ & $\begin{array}{l}\text { Belajar melalui memanipulasi } \\
\text { dan praktik }\end{array}$ \\
\hline Mengingat dengan asosiasi viasual & Biasanya pembicara yang fasih & $\begin{array}{l}\text { Menghafal dengan cara ber- } \\
\text { jalan dan melihat }\end{array}$ \\
\hline $\begin{array}{l}\text { Biasanya tidak terganggu oleh } \\
\text { keributan }\end{array}$ & Lebih suka musik daripada seni & $\begin{array}{l}\text { Menggunakan jari sebagai pe- } \\
\text { nunjuk ketika membaca }\end{array}$ \\
\hline $\begin{array}{l}\text { Mempunyai masalah untuk mengi- } \\
\text { kuti instruksi verbal kecual;i jika } \\
\text { ditulis, dan seringkali meminta ban- } \\
\text { tuan orang untuk mengulanginya }\end{array}$ & $\begin{array}{l}\text { Belajar dengan mendengarkan dan } \\
\text { mengingat apa yang didiskusikan } \\
\text { daripada yang dilihat }\end{array}$ & $\begin{array}{l}\text { Banyak menggunakan isyarat } \\
\text { tubuh }\end{array}$ \\
\hline Pembaca cepat dan tekun & $\begin{array}{l}\text { Suka berbicara, suka berdiskusi dan } \\
\text { menjelaskan sesuatu panjang lebar }\end{array}$ & $\begin{array}{l}\text { Tidak dapat duduk diam untuk } \\
\text { waktu yang lama }\end{array}$ \\
\hline $\begin{array}{l}\text { Lebih suka membaca daripada } \\
\text { dibacakan }\end{array}$ & $\begin{array}{l}\text { Mempunyai masalah dengan peker- } \\
\text { jaan-pekerjaan yang melibatkan } \\
\text { visualisasi }\end{array}$ & $\begin{array}{l}\text { Tidak dapat mengingat geografi, } \\
\text { kecuali jika pernah berada } \\
\text { ditempat itu }\end{array}$ \\
\hline $\begin{array}{l}\text { Membutuhkan pandangan dan tu- } \\
\text { juan yang menyeluruh dan bersikap } \\
\text { waspada sebelum secara mental } \\
\text { merasa pasti tentang suatu masalah }\end{array}$ & $\begin{array}{l}\text { Lebih pandai mengeja dengan } \\
\text { keras daripada menuliskannya }\end{array}$ & $\begin{array}{l}\text { Menggunakan kata-kata yang } \\
\text { mengandung aksi }\end{array}$ \\
\hline $\begin{array}{l}\text { Mencoret-coret tanpa arti selama } \\
\text { berbicara dalam pembelajaran }\end{array}$ & \multirow[t]{5}{*}{$\begin{array}{l}\text { Lebih suka gurauan lisan daripada } \\
\text { membaca komik }\end{array}$} & $\begin{array}{l}\text { Menyukai buku-buku yang ber- } \\
\text { orientasi pada plot }\end{array}$ \\
\hline $\begin{array}{l}\text { Lupa menyampaikan pesan verbal } \\
\text { kepada orang lain }\end{array}$ & & Kemungkinan tulisannya jelek \\
\hline $\begin{array}{l}\text { Sering menjawab pertanyaan de- } \\
\text { ngan singkat, ya atau tidak }\end{array}$ & & Ingin melalkukan segala sesuatu \\
\hline $\begin{array}{l}\text { Lebih suka melakukan demontrasi } \\
\text { daripada pidato }\end{array}$ & & $\begin{array}{l}\text { Menyukai permainan yang me- } \\
\text { nyibukkan }\end{array}$ \\
\hline Lebih suka seni daripada musik & & \\
\hline
\end{tabular}

Sumber: de Porter dan Hernacki, 2005

folio dapat dibedakan dalam dua bentuk yaitu portofolio proses dan portofolio produk. Sebagai instrumen penilaian portofolio difokuskan pada dokumen kerja siswa yang produktif, sebagai bukti tetang apa yang dapat dilakukan oleh siswa.

Portofolio siswa untuk penilaian merupakan kumpulan produksi siswa, berisi berbagai jenis karya siswa misalnya, hasil praktek yang dilaporkan secara tertulis, gambar atau laporan hasil pengamatan siswa berkaitan dengan mata pelajaran, analisis situasi, deskripsi dan diagram pemecahan masalah, penyelesaian soal-soal, hasil tugas pekerjaan rumah, laporan kerja kelompok, hasil kerja yang diperoleh menggunakan alat rekam (video, audio, dan komputer), foto copy piagam atau tanda penghargaan yang pernah diterima, hasil karya dalam mata pelajaran yang tidak ditugaskan oleh guru (tapi masih sesuai), cerita tentang kesenangan atau ketidak senangan terhadap mata pelajaran tertentu, cerita tentang 
usaha sendiri dalam mengatasi hambatan psikologis atau usaha peningkatan diri dalam mempelajari mata pelajaran tertentu serta laporan tentang sikap siswa terhadap pelajaran.

Manfaat dari penilaian portofolio antara lain:

1) Dapat memberikan gambaran yang utuh tentang perkembangan kemampuan siswa; 2) Merupakan penilaian autentik; 3) Merupakan teknik penilaian yang dapat mendorong siswa mencapai hasil yang lebih baik dan lebih sempurna, dapat belajar optimal tanpa merasa tertekan; 4) Menumbuhkan motivasi belajar siswa; dan 5) Mendorong para orang tua siswa untuk aktif terlibat dalam proses pembelajaran siswa (Sanjaya W, 2007)

Menurut Sanjaya, prinsip-prinsip yang harus diperhatikan dalam penilaian portofolio adalah saling percaya, keterbukaan, kerahasian, milik bersama, kepuasan dan kesesuaian, budaya pembelajaran, refleksi serta berorientasai pada proses dan hasil.

Menggunakan penilaian portofolio dalam proses pembelajaran melalui tahapan antara lain: menentukan tujuan portofolio, menentukan isi portofolio, menentukan kriteria dan format penilaian, pengamatan dan penentuan bahan portofolio serta menyusun dokumen portofolio. Penilaian portofolio merupakan penilaian proses pembelajaran yang dilakukan oleh guru untuk mengetahui perkembangan kemampuan siswa secara komprehensif.

\section{Metodologi Penelitian}

Penelitian ini merupakan penelitian deskriptif kualitatif melalui implementasi lesson study dalam pembelajaran. Subyek penelitian adalah siswasiswi kelas VIII SMP Sekolah Alam dan Sains Aljannah Jakarta, dilakukan pada semester genap tahun ajaran 2008/2009.

Prosedur penelitian dimulai dengan melakukan analisis kebutuhan dengan memberikan kuesioner kepada guru dan siswa, wawancara, dan observasi kelas. Tindakan selanjutnya adalah melakukan aktifitas sesuai tahapan lesson study (plan, do, see). Data yang diperoleh dari obsevasi, catatan lapangan, dan hasil portofolio dari aktivitas siswa dianalisis dengan teknik deskriptif kualitatif.

\section{Hasil Penelitian dan Pembahasan}

Implementasi lesson study dalam pembelajaran kimia dalam IPA terpadu. Dalam merancang pembelajaran menggunakan tahap-tahap dari lesson study, yakni plan, do, see. Pada tahap plan, dirancang semua komponen yang mendukung proses pembelajaran sesuai kondisi dan gaya belajar siswa dan termasuk membuat instrumen observasi. Data mengenai gaya belajar dari 10 (sepuluh) siswa kelas VIII yang diperoleh dari sekolah yaitu 8 (delapan) siswa mempunyai gaya belajar Auditori dan 2 (dua) siswa Visual. Dari 10 (sepuluh) siswa tersebut 1 (satu) orang down syndrom, 1 (satu) orang kategori cerdas berbakat (CB), dan 1 (satu) orang lambat belajar (slow learner). Pelaksanaan pembelajaran 4 (empat) kali pertemuan, yaitu: 1) Pengenalan awal zat adiktif dan psikotropika; 2) Bahaya zat adiktif dan psikotropika bagi tubuh manusia; 3) Zat aditif makanan; 4) Revieu zat adiktif makanan , zat adiktif dan psikotropika.

\section{Pembelajaran Pertama Prencanaan (plan).}

Pada tahap ini membuat rencana pembelajaran, materi pelajaran yang disepakati adalah Pengenalan Psikotropika dan Zat Adiktif beserta jenis-jenisnya serta bahayanya. Dalam skenario pembelajaran disepakati aktivitas siswa adalah menonton film "Penyalahgunaan Narkoba". Evaluasi yang direncanakan membuat dua portofolio yang dihasilkan oleh siswa.

Portofolio pertama yaitu tugas individu berupa hasil pengamatan siswa terhadap film yang diputar, refleksi pembelajaran dan foto-foto, dilaporkan dalam bentuk tulisan dan gambar. Portofolio kedua juga untuk tugas individu berupa lembaran kerja siswa berisi pertanyaan yang harus dijawab siswa untuk memperoleh umpan balik pemahaman materi dan pendapat siswa pada pelaksanaan proses pembelajaran.

\section{Tahap Pelaksanaan (do)}

Pada awal pembelajaran, guru menyampaikan tujuan pembelajaran dan aktivitas yang akan dilakukan oleh siswa. Topik pertama adalah Pengenalan Psikotropika, aktifitas siswa menonton film "Penyalahgunaan Narkoba" Untuk portofolio pertama guru menginstruksikan setiap 
Tabel 2. Jumlah pengamatan Siswa Kelas VIII terhadap Film "Penyalahgunaan Narkoba"

\begin{tabular}{|c|c|}
\hline Nama & Jumlah Pengamatan \\
\hline Siswa 1 & 13 \\
\hline Siswa 2 & 13 \\
\hline Siswa 3 & 11 \\
\hline Siswa 4 & 28 \\
\hline Siswa 5 & 13 \\
\hline Siswa 6 & 7 \\
\hline Siswa 7 & 13 \\
\hline Siswa 8 & 16 \\
\hline Siswa 9 & 13 \\
\hline Siswa 10 & 12 \\
\hline
\end{tabular}

siswa menuliskan sebanyak-banyaknya apa yang diamati ketika nonton film atau menggambarkan hasil pengamatan dari film yang diputar. Jumlah pengamatan yang diamati siswa bervariasi, dapat dilihat pada Tabel 2.

Beberapa siswa menghubungkan pengamatan nonton film pada lingkungan hidup, dan menuliskan dalam portofolio mereka supaya menjauhi narkoba dan menyadari bahwa zat adiktif dan psikotropika merupakan bahan-bahan berbahaya.

Portofolio kedua, siswa diminta mengisi lembar kerja yang berisi pertanyaan-pertanyaan tentang materi yang dipelajari dan pendapat siswa pada pembelajaran.

\section{Refleksi.}

Sebagian siswa aktif menonton film yang ditayangkan, sambil membuat catatan, ada juga yang membuat gambar. Dari 10 (sepuluh) hasil portofolio yang dikumpulkan setelah menonton film, hanya 4 (empat) siswa yang membuat dalam bentuk gambar sedangkan 6 (enam) siswa lainnya dalam bentuk tulisan. Tiga siswa menuliskan dengan tidak serius, terlihat dari jawaban yang diberikan pada isian mereka dan tujuh siswa lainnya serius.

Sebagian siswa aktif menonton film yang ditayangkan, sambil membuat catatan, ada juga yang membuat gambar. Siswa 6 mencatat paling sedikit yaitu 7 (tujuh) pengamatan, Jumlah pengamatan paling banyak adalah siswa 4 yakni 28 (duapuluhdelapan) pengamatan. Berdasarkan hasil tes gaya belajar siswa, siswa 6 mempunyai kecenderungan gaya belajar auditori dan ter- golong siswa down syndrom yang selalu didampingi oleh seorang shadow. Siswa ini bisa menulis pengamatan dengan baik, namun kalimat yang digunakan sulit untuk dimengerti karena hubungan antar kata masih belum berkaitan tapi guru bisa menangkap isi nya. Siswa ini belajar dengan mendengarkan, tetapi tidak bisa menuangkan jawaban dalam bentuk tulisan sehingga perlu dibantu oleh pendamping (shadow), hal ini terlihat pada isian portofolio kedua yang membutuhkan jawaban dalam bentuk uraian. Berbeda siswa 4, siswa normal yang juga mempunyai gaya belajar auditori, dapat menulis pengamatan paling banyak, pengamatan dibuat dalam bentuk alur cerita yang cukup lengkap dan diakhiri dengan sebuah seruan untuk menjauhi narkoba dan rokok. Siswa 5 (Cerdas Berbakat) tergolong gaya belajar visual, selalu membawa laptop dalam mengikuti pembelajaran di kelas selalu menyendiri. Membuat tugas menggunakan labtop dan tidak terbiasa menulis oleh karena itu tulisannya sukar dimengerti. Portofolio kedua makin susah bagi nya untuk menulis karena yang membutuhkan penjelasan. Siswa ini mengalami kesulitan bila disuruh menulis. Hasil pengamatan yang dilaporkannya selain dari film dia juga menjajikan pengamatannya berupa implementasi film tersebut dalam kehidupan. Hasil pengamatan yang dilaporkan siswa yang lain dalam portofolio pertama dan kedua ada yang mengerjakan dengan serius dan kurang serius.

\section{Pembelajaran Kedua Perencanaan (plan)}

Pada pembelajaran kedua ini materi yang akan disampaikan yaitu: Bahaya Zat Adiktif dan Psikotropika Terhadap Tubuh Manusia. Portofolio yang digunakan berupa catatan lapangan, refleksi pembelajaran dan foto-foto.

Dalam skenario pembelajaran, sebelum pertemuan kedua masing-masing siswa diberi tugas tentang bahaya zat adiktif dan psikotropika dengan topik yang berbeda untuk dipresentasikan pada pembelajaran pertemuan kedua. Guru juga mempersiapkan bahan ajar alternatif berupa media atau gambar maupun tulisan tentang pengaruh psikotropika dan zat adiktif terhadap tubuh, dan instrumen penilaian untuk observer. Ada 10 media yang disiapkan, berupa gambar 
maupun tulisan alur kerja atau pengaruh psikotropika dan zat adiktif yang dipotong dan ditempel pada sebuah kardus untuk dipelajari dan dipresentasikan didepan kelas.

\section{Pelaksanaan (do)}

Pada awal pembelajaran guru menanyakan tugas yang telah diberikan untuk dipresentasikan, akan tetapi tidak ada siswa yang mengerjakan. Guru membuka pelajaran dan menjelaskan tujuan pembelajaran dan kegiatan yang akan dilakukan. Guru memberikan bahan ajar alternatif yang telah disiapkan kepada masing-masing siswa, yaitu potongan kardus yang telah berisi gambar maupun tulisan untuk dipelajari dan dipresentasikan didepan kelas. Selanjutnya, guru menawarkan urutan presentasi pada siswa, untuk tampil pertama hanya 1 orang siswa yang angkat tangan yaitu siswa 2, dan guru memberi kesempatan lagi pada siswa lain untuk tampil kedua, hanya siswa 5 yang angkat tangan. Selanjutnya guru menentukan urutan yang akan tampil yaitu siswa 4.9,8,1, 7,6,3 dan 10. Materi presentasi yang diterima masing-masing siswa dapat dilihat pada Tabel 3.

Tabel 3.Bahan Materi Presentasi Siswa Kelas VIII

\begin{tabular}{|c|l|}
\hline Nama & \multicolumn{1}{|c|}{ Jumlah Pengamatan } \\
\hline Siswa 1 & Dampak Mengkonsumsi Alkohol \\
\hline Siswa 2 & $\begin{array}{l}\text { Perjalanan Alkohol dalam Tubuh } \\
\text { Manusia }\end{array}$ \\
\hline Siswa 3 & Kebenaran Tentang Nikotin \\
\hline Siswa 4 & $\begin{array}{l}\text { Bagaimana Narkoba Dapat } \\
\text { Menghilangkan Koordinasi Tubuh }\end{array}$ \\
\hline Siswa 5 & $\begin{array}{l}\text { Alur Kerja Narkotika di Dalam } \\
\text { Tubuh }\end{array}$ \\
\hline Siswa 6 & $\begin{array}{l}\text { Pengaruh Obat-obatan Terlarang } \\
\text { Terhadap Kerja Sistem Saraf }\end{array}$ \\
\hline Siswa 7 & Narkoba Hancurkan Kerja Otak \\
\hline Siswa 8 & Vitamin Khusus Otak \\
\hline Siswa 9 & $\begin{array}{l}\text { Situasi Orang Minum Minuman } \\
\text { Beralkohol }\end{array}$ \\
\hline Siswa 10 & $\begin{array}{l}\text { Kemampuan Tubuh yang } \\
\text { Terpengaruh Narkoba }\end{array}$ \\
\hline
\end{tabular}

Pada saat presentasi siswa pertama, tidak semua siswa memperhatikan karena masih ada siswa yang belum siap, dan ada juga siswa yang berdiskusi teman sebelahnya. Oleh karena sebagian siswa hanya berbekal bahan yang diberikan guru, maka beberapa diantaranya ketika melakukan presentasi terkesan membaca dan ketika ditanya oleh beberapa siswa lain tidak dapat menjawab.

\section{Refleksi}

Aktivitas siswa cenderung meningkat dengan adanya presentasi masing-masing siswa di depan kelas. Pembelajaran pertama yang menghasilkan portofolio dalam bentuk tulisan, sedangkan portofolio pada pembelajaran kedua berupa presentasi (lisan) yang diabadikan dalam foto. Siswa-siswa yang memiliki gaya belajar auditori lebih bersemangat diberi tugas presentasi karena salah satu ciri gaya belajar auditori suka bercerita. Pada waktu presentasi terlihat peningkatan aktivitas siswa, interaksi siswa dengan siswa, dan guru dengan siswa. Siswa 5 (CB) pada waktu presentasi bicara cepat, merupakan ciri gaya belajar visual, dapat menjelaskan dengan contoh yang nyata dalam kehidupan, bila menjawab pertanyaan dapat memberi jawaban yang relatif panjang. Artinya ada pengaruh tingkat kecerdasan superiornya, menurut teori, gaya belajar visual akan memberi jawaban singkat.

\section{Pembelajaran Ketiga Perencanaan (plan)}

Membuat rencana proses pembelajaran dan skenario pembelajaran ketiga direncanakan menggunakan metode permainan dan pertandingan berkelompok, mempersiapkan perangkat pembelajaran yang diperlukan, dan membuat instrumen observasi. Ada 3 (tiga) macam portofolio yaitu: 1) Hasil pengamatan dan pengklasifikasian zat aditif dalam makanan dan minuman ringan; 2) Membuat gambar dan lagu dengan tema zat aditif, zat adiktif dan psikotropika; dan 3) catatan lapangan dan foto-foto siswa.

Alur kegiatan pembelajaran adalah permainan head-leg, detect it, puzzle dan diakhiri dengan be an artist.

\section{Pelaksanaan (do)}

Pada awal pembelajaran guru menyampaikan tujuan pembelajaran dan menjelaskan cara permainan dan pertandingan antar kelompok. Guru membagi siswa menjadi 5 (lima) kelompok, masing-masing kelompok 2 (dua) siswa yang 
beperan sebagai Head dan Leg. Pembagian kelompok dapat dilihat pada Tabel 4.

Tabel 4. Kelompok Permainan Head-Leg

\begin{tabular}{|c|c|c|}
\hline Kelompok & Head & Leg \\
\hline 1 & Siswa 5 & Siswa 8 \\
2 & Siswa 7 & Siswa 9 \\
3 & Siswa 1 & Siswa 10 \\
4 & Siswa 3 & Siswa 2 \\
5 & Siswa 6 & Siswa 4 \\
\hline
\end{tabular}

Head-leg adalah permainan yang membutuhkan kerjasama antara dua orang dalam satu tim. Head bertugas sebagai penerima pesan dari Leg, leg bertugas mengumpulkan serpihan informasi yang terdapat dalam kardus. Informasi tersebut harus menunjukkan key word jenis zat aditif makanan, ketika serpihan informasi tersebut ditemukan, maka ditempelkan di papan tulis dan head bertugas menebak key word. Tim yang menang adalah tim yang mampu membawa serpihan sesuai key word secepat mungkin dan menebak key word dengan tepat. Selama permainan seluruh siswa mengikuti proses pembelajaran dengan sangat gembira, kecuali siswa 9 yang merasa sangat tidak senang namun tetap mencoba mengikuti dan menikmatinya.

Permainan kedua adalah detect it, mereka masih tetap bekerja dalam tim, mereka diberikan media berupa beberapa jenis makanan ringan, kemudian siswa diminta mendeteksi zat aditif yang makanan tersebut, sambil menggolongkan ke dalam jenis masing-masing (zat pewarna, pemanis, penyedap rasa dan stimulan). Untuk menentukan pemenang yaitu kelompok yang paling cepat mendeteksi dan sesuai dengan penggolongan. Tugas untuk portofolio 1(satu) yaitu mengklasifikasikan zat aditif dalam makanan dan minuman, diakukan pada saat siswa mengikuti permainan detect it. Mereka dibuat berkelompok, kemudian diberikan kardus yang berisi beberapa makanan dan minuman ringan. Pembagian kelompok serta makanan dan minuman yang diterima dapat dilihat pada Tabel. 5

Penilaian portofolio 1 (satu) menunjukkan kemampuan siswa mengklasifikasikan jenis-jenis zat aditif makanan. Guru mendiskusikan dan menjelaskan klasifikasi zat aditif dalam makanan dan minuman yang telah dikerjakan siswa dan siswa menilai secara lisan pekerjaan yang telah dibuat dalam kelompok.

Tugas untuk portofolio kedua dan ketiga dilakukan bersamaan. Siswa boleh memilih membuat lagu atau gambar terlebih dahulu. Tema yang diberikan adalah zat aditif makanan, zat adiktif dan psikotropika. Siswa dapat memilih tema yang disukai. Setelah selesai permainan detect it,

Tabel 5. Pembagian Kelompok Siswa Kelas VIII dalam Permainan Detect it Serta Daftar Makanan dan Minuman Ringan yang Diterima.

\begin{tabular}{|c|c|c|}
\hline $\begin{array}{c}\text { Kelom- } \\
\text { pok }\end{array}$ & Siswa & Makanan dan Minuman Ringan \\
\hline 1 & Siswa 4 - Siswa 5 & $\begin{array}{l}\text { Mountea rasa Blackcurrant } \\
\text { Inaco Nata de Aloe Vera } \\
\text { Twist Ball } \\
\text { Slai O'lai rasa Stroberi }\end{array}$ \\
\hline 2 & Siswa 3 - Siswa 10 & $\begin{array}{l}\text { Sea Crunch rasa udang } \\
\text { Toya Toya } \\
\text { Jelly Drink rasa jambu } \\
\text { Fruit Tea rasa jambu }\end{array}$ \\
\hline 3 & Siswa 1 - Siswa 2 & $\begin{array}{l}\text { Chiki Balls rasa ayam panggang } \\
\text { Happy jus rasa Blackcurrant } \\
\text { Yuppi Milly Moos } \\
\text { Richeese Rolls }\end{array}$ \\
\hline 4 & Siswa 7 - Siswa 8 & $\begin{array}{l}\text { Richeese 'ahh } \\
\text { Soda Mie rasa sambal balado } \\
\text { Nutrijel rasa jeruk } \\
\text { Permen Tango rasa fruity sweety }\end{array}$ \\
\hline 5 & Siswa 6 - Siswa 9 & $\begin{array}{l}\text { Nabati Siip } \\
\text { Vita Pudding rasa coklat } \\
\text { Tini Wini Biti rasa susu } \\
\text { Extra Joss rasa anggur Burst }\end{array}$ \\
\hline
\end{tabular}


permainan berlanjut dengan permainan puzzle. Kelompok yang pertama yang berhasil menyelesaikan permainan detect it berhak mendapat amplop yang berisi puzzle, siswa ditugaskan menebak tulisan pada puzzle.

\section{Refleksi}

Pada portofolio pertama siswa dalam kelompok masih mengalami kesulitan mengklasifikasikan jenis-jenis zat aditif makanan, hanya dua kelompok yang mengklasifikasikan dengan benar, sedangkan tiga kelompok lainnya masih salah mengklasifikasikannya. Penilaian dari portofolio kedua dan ketiga, kelompok 1 terlihat bersemangat dan bisa menyelesaikan gambar dan lagu dengan sempurna, kelompok 4 hanya membuat lagu saja dan tidak membuat gambar karena merasa tidak mampu. Kelompok 5 tidak membuat sama sekali baik lagu maupun gambar karena lama dalam mengerjakan permainan detect it, dikarenakan siswa 9 dan 6 tidak dapat bekerjasama maksimal dalam menyelesaikannya. Setelah selesai permainan detect it. Kelompok 1 juga merupakan pasangan yang paling cepat menebak tulisan pada puzzle, sedangkan pasangan yang paling lambat menebak tulisan pada puzzle adalah kelompok 3. Kelompok 1 (siswa 5 dan siswa 4) tidak bekerjasama dengan baik siswa 5 dominan dalam kelompok karena tidak memberi kesempatan siswa 4 membantu. Siswa 5 ini termasuk siswa yang perfectionist, dia harus mengerjakan pekerjaan dengan sempurna, hal ini merupakan ciri siswa visual. Pada akhir pembelajaran semua kelompok mengumpulkan tugas mereka, termasuk kelompok yang belum selesai.

\section{Pembelajaran Keempat \\ Perencanaan (plan)}

Guru membuat rencana proses pembelajaran, rancangan pembelajaran hampir sama dengan pembelajaran kedua, bedanya bahan yang digunakan untuk dipresentasi berbentuk gambar alur suatu cerita dan siswa diminta menginterpretasikan gambar tersebut. Rancangan Portofolio siswa terakhir adalah siswa ditugaskan membuat suatu rencana kedepan setelah mempelajari zat aditif makanan, zat adiktif dan psikotropika sesuai pemikiran dan pemahaman mereka. Membuat instrumen observasi proses pembelajaran.

\section{Pelaksanaan (do)}

Pada awal pembelajaran guru menjelaskan tujuan pembelajaran dan tugas yang akan dikerjakan siswa. Masing-masing siswa mengerjakan tugas menginterpretasikan gambar yang diberikan. kemudian secara bergiliran masingmasing siswa maju kedepan mempresentasikan tugas mereka. Sambil menunggu giliran beberapa siswa mencoret-coret gambar yang ada untuk memudahkan membaca gambar. Selanjutnya, siswa diberi waktu untuk mengerjakan tugasnya. Masing-masing siswa mengerjakan tugas dalam bentuk karangan bebas yang menunjukkan pemahaman, dan pemikiran, serta wawasannya tentang materi zat aditif, zat adiktif dan psikotropika untuk masa mendatang.

\section{Refleksi}

Terlihat semua siswa aktif dan masing-masing siswa mengerjakan tugas menginterpretasi dari gambar yang diberikan. Semua siswa secara bergilir presentasi kedepan, ada 7 siswa yang membuat coretan pada gambar, coretan tersebut ada yang cukup bermakna, mereka terlihat aktif dan bersemangat. Tugas portolio terakhir membuat karangan bebas tentang rencana masa yang akan datang mengenai materi zat aditif, zat adiktif dan psikotropika. Masing-masing siswa terlihat bervariasi dalam mengemukakan pemikirannya, mulai dari memperdalam ilmu dan wawasan tentang zat adiktif dan psikotropika (6 siswa), membuat rokok yang tidak mengandung zat adiktif (1 siswa), membuat makanan tanpa bahan aditif (1 siswa), sampai membuat bom (1 siswa). Bahkan ada satu siswa yang tidak mengemukakan pemikirannya dalam tulisan yang ditugaskan tapi menuliskannya di laptop dikumpulkan dalam bentuk softcopy. Siswa ini tergolong kategori siswa cerdas berbakat dengan IQ superior, suka menyendiri, asyik bekerja dengan laptopnya.

\section{Simpulan dan Saran Simpulan}

Implementasi lesson study menggunakan penilaian portofolio menunjukkan bahwa siswa dengan gaya belajar visual, aktivitas belajarnya meningkat jika menggunakan portofolio jenis tulisan dan gambar. Siswa dengan gaya belajar 
auditori, aktivitas belajarnya meningkat jika menggunakan portofolio jenis lisan atau lagu, sehingga siswa kelas VIII SMP Sekolah Alam Aljannah Jakarta pada mata pelajaran Kimia dalam IPA Terpadu sebagai berikut: 1) Gaya belajar siswa berpengaruh terhadap peningkatan aktifitas belajar; 2) Metode pembelajaran yang bervariasi meningkatkan aktifitas belajar; 3) Kecenderungan gaya belajar tertentu dalam diri siswa tidak menutup kemungkinan munculnya gaya belajar lain dalam proses pembelajaran; dan 4) Implementasi lesson study dalam pembelajaran IPA terpadu menggunakan penilaian portofolio pada siswa yang mempunyai kemampuan dan gaya belajar bervariasi dapat meningkatkan aktivitas belajar siswa.

\section{Saran}

Atas dasar simpulan maka guru disarankan kepada guru agar menerapkan: a) lesson study pada materi pokok kimia lainnya dalam kelas yang sama; b) lesson study dalam pembelajaran mata pelajaran lainnya di SMP Alam Aljannah Jakarta; c) penilaian portofolio untuk setiap materi pokok yang dipelajari dan mengembanagkan modelmodel pembelajaran lainnya sesuai dengan karakteristik, materi, dan variasi gaya belajar siswa.

\section{Pustaka Acuan}

De Porter, dan B. Hernacki, M. 2005. Quantum Learning. Bandung; Kaifa.

Departemen Pendidikan Nasional, 2004. Mengenal Pendidikan Terpadu. Jakarta: Direktorat Pendidikan Luar Biasa. Direktorat Jenderal Pendidikan Dasar dan Menengah.

Hamalik, Oemar. 2007. Proses BelajarMengajar. Jakarta: Bumi Aksara

Hendayana, Sumar, Didi Suryadi, Muchtar A Karim, Sukirman. 2007. Lesson study. Bandung: UPI Press. Jasmin, Yulia. 2007. Mengajar Berbasis Multiple Intelligences. Bandung: Nuansa.

Johnson, Elaine B . 2007. Contextual Teaching and Learning. Bandung: Penerbit MLC

Nasution, S. 2008. Berbagai Pendekatan dalam Proses Belajar \& Mengajar. Jakarta: Bumi Aksara

Sanjaya, W. 2007. Strategi Pembelajaran. Jakarta: Kencana.

S. Sumarna dan M Hatta. 2004. Penilaian Portofolio. Bandung : Penerbit PT Remaja Rosdakarya.

Tierney, Robert J, Mark A. Carter, Laura E Desai. 1991. Portofolio Assesment in the Reading-Writing

Classroom. Norwood, MA: Christopher-Gordon Publisher, Inc. 